\title{
Minutes of the ATLA Business Meeting
}

By Stephen Sweeney, St. John Vianney Theological Seminary, Secretary Friday, June 15, 2018

The Business meeting was convened by Board President Matthew Ostercamp at 2:00 p.m. President Ostercamp did not deliver a Presidential Address.

Stephen Sweeney presented the Secretary's report. Members of the Tellers Committee were Jim Darlack, Rebekah Bédard, and David Kriegh. Jim Darlack chaired the committee for this election cycle. The Committee received the election results via email from Survey and Balloting Systems, confirmed the results, and relayed them to the Secretary. The membership elected Ellen Frost, Armin Siedlecki, Shanee' Yvette Murrain, and Matthew Thiesen for the 2018-2021 term of office.

Also in this election cycle (which ran January 4-January 31), members were asked to consider a bylaws question on Membership categories. To that end, the Board of Directors had proposed a replacement for the Lifetime Membership category in the ATLA Bylaws. With $43 \%$ of the membership voting (including mail-in and electronic ballots), the bylaws proposal passed by a margin of $90 \%$ in favor. The Secretary's report was accepted by voice vote of the members.

President Ostercamp welcomed the incoming board members and thanked the three outgoing board members, Lucy Chung, Tracy Iwaskow, and Tim Lincoln. President Ostercamp announced the 20182019 officers for the Board of Directors.

President Ostercamp recognized recently retired ATLA members. Memorials were offered for members who have passed away, including Thomas Edward (Ed) Camp, Myrta Ann Latimer Garrett, Seth Kasten, John Meeks, William M. Robarts, Richard D. (Mark) Spoor, and Joseph Troutman. Memorials were concluded by the singing of the Kontakion.

Incoming President Jennifer Bartholomew thanked Matthew Ostercamp for his service as President and accepted the gavel. A motion was made to adjourn the meeting. The meeting was adjourned at 3:00 p.m. 